\title{
Tugas Dan Fungsi Balai Harta Peninggalan Semarang Sebagai Kurator Kepailitan Berdasarkan Undang-Undang Nomor 37 Tahun 2004 Tentang Kepailitan Dan Penundaan Kewajiban Pembayaran Utang
}

\section{Moh Kurniawan*}

* Mahasiswa Program Magister (S2) Ilmu Hukum Fakultas Hukum UNISSULA Semarang, PNS Kemenkumham email : bhpsemarang25@gmail.com

\section{Abstrak}

Peran dari Balai Harta Peninggalan berkurang, sejak munculnya kurator swasta, apalagi Pengadilan Niaga berdasarkan permintaan debitor atau kreditor cenderung menggunakan kurator swasta dari pada menggunakan Balai Harta Peninggalan yang ada, dan dalam praktek pun Balai Harta Peninggalan kurang mendapatkan perhatian. Hal ini dikarenakan ada anggapan bahwa Balai Harta Peninggalan lamban dalam menjalankan tugasnya dan sumber daya manusianya yang kurang jika di bandingkan dengan kurator swasta.

Tujuan penelitian yang ingin dicapai dari penelitian ini adalah Untuk mengetahui tugas dan fungsi Balai Harta Peninggalan Semarang sebagai kurator Kepailitan berdasarkan Undang-Undang Nomor 37 Tahun 2004 tentang Kepailitan dan Penundaan Kewajiban Pembayaran Utang.dan mengetahui eksistensi Balai Harta Peninggalan Semarang sebagai kurator kepailitan setelah adanya kurator swasta

Penelitian ini menggunakan metode pendekatan metode pendekatan yuridis sosiologis tidak hanya ditinjau dari kaidah hukum saja, tetapi juga berusaha untuk menelaah keterkaitan antara faktor yuridis dengan faktor sosiologis. Faktor yuridis dalam penelitian ini adalah Undang-Undang Nomor 37 Tahun 2004, sedangkan faktor sosiologisnya adalah mengetahui pelaksanaan undang-undang tersebut dalam hal tugas dan fungsi Balai Harta Peninggalan dalam melakukan pengurusan dan pemberesan harta pailit debitur

Dari data-data yang berhasil dikumpulkan dalam penulisan ini, baik data primer maupun data sekunder didapatkan hasil penelitian bahwa tugas kurator tidaklah mudah. Tugas kurator adalah melaksanakan pengurusan dan pemberesan harta pailit. Eksistensi Balai Harta Peninggalan dibandingkan dengan kurator swasta menunjukkan penurunan eksistensi sebagai kurator yang disebabkan oleh berbagai faktor.

Kata kunci : BHP, Tugas, Eksistensi

\section{Abstract}

The role of Probate Court (BHP) has decreased since the presence of private receivers. Moreover, Pengadilan Niaga (Trade Court), according to debtors and creditors' demands prefers private receivers to Probate Court, and in fact, Probate Court gets less attention. It is caused by an opinion that Probate Court clumsily runs its duty and that its human resources are not enough compared with the private 
receivers.

The goals of the research are to understand and to analyze the responsibility of Probate Court as a receiver after the validity of law No. 372004 of bankruptcy and the obstacles faced by Probate Court in management and settlement of bankruptcy. Existence with currator non goverment.

The research applies methods of juridical-empirical approach, an approach that uses secondary data in advance and followed by primary data in field that will be used to answer the emerged problems.

A research says: in the context of bankruptcy, the responsibility for failures and mistakes done by Probate Court is regulated in Article 72 of law No. 372004 of bankruptcy which has not given the law certainty as there is no definite punishments. Therefore, the receiver's responsibility for failures and or mistakes can be different in form and is adjusted with the level of mistakes and loss.

Probate Court as a receiver has full responsibilities for making up loss caused by their neglects and or mistakes, based on article 80 Stbl 1872 No. 166 of Instruction for Probate Court in Indonesia.

Probate Court in running its duty and authority as a receiver finds some obstacles such as: bureaucracy, juridical, administration, and human resources.

Key words: BHP, Assigment, Existence.

\section{PENDAHULUAN}

Krisis moneter yang terjadi di Indonesia pada tahun 1998 membuat utang menjadi bengkak luar biasa sehingga mengakibatkan banyak sekali debitur tidak mampu membayar utang-utangnya. Disamping itu, kredit macet di perbankan Indonesia makin membumbung tinggi karena krisis moneter ${ }^{1}$.

Dunia usaha merupakan dunia yang paling menderita dan merasakan dampak krisis yang melanda. Negara Indonesia memang tidak sendirian dalam menghadapi krisis tersebut, namun tidak dapat dipungkiri bahwa negara kita adalah adalah salah satu negara yang paling menderita dan merasakan akibatnya. Selanjutnya tidak sedikit dunia usaha yang gulung tikar, sedangkan yang masih dapat bertahanpun hidupnya menderita.

Dengan adanya krisis moneter yang melanda di Indonesia telah memberikan dampak yang tidak menguntungkan terhadap perekonomian nasional sehingga menimbulkan kesulitan besar terhadap dunia usaha dalam menyelesaikan utang-piutang untuk meneruskan kegiatan perekonomian.

Para pelaku usaha di bidang perekonomian yang biasanya juga bertindak sebagai debitor menjadi terhambat dalam melaksanakan kewajibannya kepada kreditor dalam hal pembayaran utang yang telah jatuh tempo.

Salah satu sarana hukum dari pihak kreditor dalam menghadapi debitur yang terlambat dalam melaksanakan kewajibannya dalam hal pembayaran utang yang telah jatuh tempo dengan melakukan permohonan pailit kepada Pengadilan Niaga. Syarat permohonan kepailitan oleh kreditor adalah debitur mempunyai dua atau lebih kreditor dan sedikitnya tidak membayar satu utang yang telah

\footnotetext{
${ }^{1}$ Adrian Sutedi, S.H. M.H, Hukum Kepailitan, (Bogor: Ghalia, 2009), hlm. 3.
} 
jatuh tempo dan telah dapat ditagih ${ }^{2}$.

Dalam perjanjian kredit terdapat adanya kreditur dan debitur yang mana perjanjian kredit tersebut dibatasi oleh tenggang waktu untuk pembayaran utang yang telah jatuh tempo. Pada saat terjadinya krisis ekonomi banyak terjadi penundaan dan terlambatnya kewajiban dalam hal pembayaran utang. Yang dimaksudkan debitur adalah orang yang mempunyai utang karena perjanjian atau undang-undang yang pelunasannya dapat ditagih di muka pengadilan, menurut Pasal 1 angka 3 Undang-Undang Kepailitan dan Penundaan Kewajiban Pembayaran Utang Nomor 37 Tahun 2004. Pengertian kreditur adalah orang yang mempunyai piutang karena perjanjian atau undang-undang yang dapat ditagih di muka pengadilan. Dalam Undang-Undang Kepailitan dan Penundaan Kewajiban Pembayaran Utang Nomor 37 Tahun 2004 objek kepailitan adalah debitur, yaitu debitur yang tidak membayar utang-utangnya kepada kreditornya. Kepailitan seorang debitur harus dinyatakan dengan putusan Pengadilan atau Hakim. Kewenangan pengadilan untuk menjatuhkan putusan kepailitan itu ditentukan secara tegas dalam Pasal 8 Undang-Undang Kepailitan dan Penundaan Kewajiban Pembayaran Utang Nomor 37 Tahun 2004. Setelah adanya putusan pernyataan pailit oleh Pengadilan yang telah memperoleh kekuatan tetap maka harus diangkat kurator dan seorang Hakim Pengawas yang ditunjuk dari Hakim Pengadilan. Dengan adanya putusan Pengadilan terhadap permohonan pailit maka pihak yang berwenang mengajukan permohonan tersebut harus mengajukan usulan pengangkatan kurator kepada Pengadilan, jika tidak ada pengajuan usulan maka Balai Harta Peninggalan diangkat selaku kurator hal ini sebagaimana diatur dalam Undang-Undang Kepailitan dan Penundaan Kewajiban Pembayaran Utang Nomor 37 Tahun 2004 Pasal 15. Kurator adalah Balai Harta Peninggalan atau orang peseorangan yang diangkat Pengadilan untuk mengurus dan membereskan harta debitor pailit di bawah pengawasan Hakim Pengawas sesuai dengan UU Nomor 37 Tahun 2004. Tugas kurator sebagaimana menurut Pasal 69 ayat 1, tugas kurator adalah melakukan pengurusan dan/atau pemberesan harta pailit. Kurator dalam undang-undang kepailitan dan penundaan kewajiban Pembayaran Utang disebutkan bahwa ada dua yaitu;

1. Balai Harta Peninggalan; atau

2. Kurator lainnya.

Tugas dan wewenang Kurator adalah :

1. Melakukan pengurusan dan atau pemberesan harta pailit;

2. Mengumumkan putusan hakim tentang pernyataan pailit dalam Berita Negara dan surat-surat kabar yang ditetapkan oleh Hakim Pengawas;

3. Menyelamatkan harta pailit, antara lain menyita barang-barang perhiasan, efek-efek, surat berharga serta uang, dan menyegel harta benda si pailit atas persetujuan haikim pengawas;

4. Menyusun inventaris harta pailit;

5. Menyusun daftar utang dan piutang harta pailit; ${ }^{3}$

Peran dari Balai Harta Peninggalan berkurang, karena Pengadilan Niaga berdasarkan permintaan

\footnotetext{
${ }^{2}$ Ibid, hlm. 39

${ }^{3}$ Ibid, hlm. 62
} 
debitor atau kreditor cenderung menggunakan kurator swasta dari pada menggunakan Balai Harta Peninggalan yang ada, dan dalam praktek pun Balai Harta Peninggalan kurang mendapatkan perhatian. Hal ini dikarenakan ada anggapan bahwa Balai Harta Peninggalan lamban dalam menjalankan tugasnya dan sumber daya manusianya yang kurang jika dibandingkan dengan kurator swasta.

Berdasarkan latar belakang tersebut maka rumusan masalah penelitian ini adalah sebagai berikut:

1. Bagaimana tugas dan fungsi Balai Harta Peninggalan Semarang sebagai kurator kepailitan berdasarkan Undang-Undang Nomor 37 Tahun 2004 tentang Kepailitan dan Penundaan Kewajiban Pembayaran Utang?

2. Bagaimana eksistensi Balai Harta Peninggalan Semarang sebagai kurator kepailitan dengan adanya kurator swasta?

Penelitian ini mempunyai tujuan yaitu: 1) Untuk mengetahui tugas dan fungsi Balai Harta Peninggalan Semarang sebagai kurator Kepailitan berdasarkan Undang-Undang Nomor 37 Tahun 2004 tentang Kepailitan dan Penundaan Kewajiban Pembayaran Utang; 2). Untuk mengetahui eksistensi Balai Harta Peninggalan Semarang sebagai kurator kepailitan setelah adanya kurator swasta.

\section{Metode Penelitian}

Metode pendekatan dalam penelitian ini menggunakan metode pendekatan yuridis sosiologis yaitu suatu penelitian yang tidak hanya menekankan pada ilmu hukum, tetapi disamping itu juga menelaah kaidah-kaidah hukum yang berlaku di dalam masyarakat ${ }^{4}$.

Dalam penelitian ini digunakan spesifikasi penelitian secara deskriptif analisis. Deskriptif, yaitu penelitian yang bertujuan melukiskan tentang suatu hal di daerah tertentu dan pada saat tertentu ${ }^{5}$. Analitis, maksudnya dikaitkan dengan teori-teori hukum yang ada dan didukung oleh data-data yang berkaitan dengan permasalahan yang akan diungkapkan yang diharapkan akan memberikan penjelasan secara cermat dan menyeluruh serta sistematis tentang tugas dan fungsi Balai Harta Peninggalan Semarang sebagai kurator dalam masalah kepailitan.

Populasi yang diteliti dalam penelitian ini adalah beberapa pihak yang ada hubungannya dengan pelaksanaan penyelesaian utang debitor terhadap kreditor melalui kepailitan, yang terdiri dari Balai Harta Peninggalan Semarang dan Pengadilan Niaga pada Pengadilan Negeri Semarang. Metode penentuan sampel dalam penelitian ini menggunakan purposive sampling yaitu metode pengambilan sampel dengan mengambil subjek tertentu dari populasi yang akan diteliit. Teknik ini dilakukan karena alasan keterbatasan waktu, tenaga, biaya sehingga tidak dapat mengambil sampel yang dekat dan jauh $^{6}$. Dalam penelitian ini sampel yang diambil adalah Balai Harta Peninggalan Semarang dan Pengadilan Niaga pada Pengadilan Negeri Semarang.

Data primer adalah data yang diperoleh secara langsung dari observasi, wawancara atau

\footnotetext{
${ }^{4}$ Ronny Hanitijo Soemitro, Metode Penelitian Hukum dan Jurimetri, (Jakarta : PT. Ghalia Indonesia, 1990$)$, hlm. . 22.

${ }^{5}$ Ibid, hlm. 35

${ }^{6}$ Suharsimi Arikunto, Prosedur Penelitian Suatu Pendekatan Praktek, (Jakarta: Penerbit Rineka Cipta, 2006$)$, hlm. 130.
} 
pengalaman peneliti. Bahan hukum sekunder, yaitu: Buku-buku ilmiah dan Makalah-makalah Hukum.

Teknik analisis data yang digunakan dalam penelitian ini adalah analisis kualitatif yaitu cara analisis yang menghasilkan data-data deskriptif analitis, maksudnya apa yang didapat responden secara tertulis dan lisan yang bersumber pada kenyataan di lapangan dikaitkan dengan data kepustakaan.

Data-data yang telah berhasil dikumpulkan dalam penelitian (baik penelitian kepustakaan maupun penelitian lapangan) dilakukan editing kemudian dianalisis untuk selanjutnya disajikan dalam bentuk uraian.

\section{HASIL PENELITIAN DAN PEMBAHASAN}

Tugas dan fungsi Balai Harta Peninggalan Semarang sebagai kurator kepailitan berdasarkan Undang-Undang Nomor 37 Tahun 2004 tentang Kepailitan dan Penundaan Kewajiban Pembayaran Utang.

Balai Harta Peninggalan (BHP) adalah unit pelaksana penyelenggaraan hukum di bidang harta peninggalan, perwalian dan kepailitan dalam lingkungan Kementerian Hukum dan Hak Asasi Manusia, yang berada di bawah dan bertanggungjawab kepada Direktur Jenderal Administrasi Hukum Umum melalui Direktur Perdata. Tugas Balai Harta Peninggalan pada Pokoknya adalah mewakili dan mengurus kepentingan orang-orang yang karena hukum atau keputusan hakim tidak dapat menjalankan sendiri kepentingannya berdasarkan peraturan perundang-undangan yang berlaku. ${ }^{7}$

Tugas Balai Harta Peninggalan sebagai kurator dalam kepailitan dapat dibagi menjadi dua bagian sesuai dengan Pasal 69 Undang-Undang Nomor 37 Tahun 2004 tentang Kepailitan, yaitu :

1. Tugas Pengurusan.

2. Tugas Pemberesan.

Tugas Balai Harta Peninggalan dalam Pengurusan Harta Pailit :

1. Mengumumkan putusan pernyataan pailit dalam dua surat kabar dan Berita Negara Republik Indonesia sekaligus memanggil debitor/kreditor untuk menghadiri rapat-rapat kreditor dan mendaftarkan tagihan. Hal ini sesuai dengan Pasal 15 ayat (4) Undang-Undang Nomor 37 Tahun 2004 tentang Kepailitan, Balai Harta Peninggalan harus secepatnya mengumumkan kepailitan tersebut dalam dua surat kabar harian yang ditunjuk oleh hakim pengawas dalam jangka waktu 5 hari setelah putusan ditetapkan

2. Melakukan inventarisasi / pencatatan harta / boedel pailit dan melakukan penyegelan jika dianggap perlu. Dalam melakukan pencatatan data pailit, Balai Harta Peninggalan Semarang melaksanakan tugasnya dengan cara sebagai berikut :

a. Paling lambat dua hari setelah menerima surat putusan pengangkatan kurator oleh Hakim maka harus membuat pencatatan harta pailit;

7 Frederick B.G. Tumbuan, Naskah Akademik Peraturan Perundang-undangan tentang Kepailitan Pengganti Failisement Verodening Stb, 195-217 jo Stb, 1906-348, BPHN Departemen Kehaikman Republik Indonesia, Tahun 1994, hlm. 40 
b. Pencatatan boleh dibuat di bawah tangan oleh kurator dengan persetujuan Hakim Pengawas;

c. Pada saat pembuatan pencatatan tersebut, para anggota panitia kreditor sementara berhak untuk hadir;

d. Setelah pencatatan dibuat, kurator harus memulai pembuatan suatu daftar yang menyatakan sifat dan jumlah piutang-piutang dan utang-utang harta pailit, nama-nama dan tempat tinggal kreditor, beserta jumlah piutangnya masing-masing;

e. Semua pencatatan tersebut di atas, oleh kurator harus diletakkan di Kepaniteraan Pengadilan, untuk dengan cuma-cuma dapat dilihat oleh siapa saja yang menghendakinya;

f. Dalam melakukan pencatatan harta pailit, kurator harus memperhatikan bukan saja harta pailit yang tidak berwujud, seperti surat-surat berharga dan tagihan-tagihan.

3. Rapat Pencocokan Utang (Verifikasi).

Pencocokkan utang dilakukan melalui rapat kreditor. Dalam waktu paling lambat 14 hari sesuai dengan Pasal 113 ayat (1) UUK-PKPU.

Jadi, secara rinci maka dalam melaksanakan rapat pencocokan utang (verifikasi), kurator melaksanakan tugasnya dengan cara sebagai berikut:

a. Memberitahukan batas akhir pengajuan tagihan dan rapat kreditor pencocokan utang, yang ditetapkan hakim pengawas, dengan surat dan iklan;

b. Menerima pengajuan segala piutang;

c. Yang disertai dengan bukti dari para kreditor;

d. Mencocokkan perhitungan piutang yang dimasukkan kreditor, dengan catatan dan keterangan debitor pailit;

e. Memasukkan utang yang diakui dan dibantah dalam suatu daftar yang terpisah;

f. Membubuhkan catatan terhadap setiap piutang, dengan pendapat apakah piutang tersebut diistimewakan atau dijamin dengan hak tanggungannya;

g. Memasukkan piutang-piutang yang dibantah serta alasannya dalam daftar piutang yang diakui sementara, atas piutang dengan hak didahulukan atau adanya hak retensi;

h. Meletakkan salinan dari masing-masing daftar piutang kepaniteraan pengadilan selama tujuh hari sebelum hari pencocokan piutang;

i. Memberitahukan dengan surat tentang peletakkan daftar piutang kepada kreditor yang dikenal;

j. Membuat daftar piutang yang diakui sementara dan yang ditolak;

k. Menarik kembali daftar piutang sementara yang diakui dan yang ditolak;

1. Menerima dengan syarat atas piutang yang dimintakan dengan penyumpahan;

m. Menuntut pembatalan pengakuan piutang atas alasan adanya penipuan;

$\mathrm{n}$. Memberikan laporan tentang keadaan harta pailit, setelah berakhirnya pencocokkan piutang dan meletakkannya dikepaniteraan pengadilan dan salinannya di kantornya;

4. Memanggil debitor pailit untuk meminta keterangan sebab-sebab menjadi pailit, apakah kawin sah atau tidak, usaha apa yang dijalankan, kemungkinan untuk dapat dilanjutkan usaha tersebut dan keterangan-keterangan lainnya yang dapat membantu memprlancar pelaksanaan tugas dan kewenangan Balai Harta Peninggalan sebagai kurator harta pailit

5. Mengirim surat kepada kantor atau instansi yang terkait dengan debitor pailit, misal: 

a. Kepada Bank-bank
b. Kepada Lurah setempat
c. Kepada Kantor Pajak domosili yang bersangkutan
d. Kepada Asuransi.

6. Memanggil Kreditor atau debitor untuk menagih atau membayar utang-utangnya sambil membawa bukti-bukti tagihan atau utang- utang.

7. Balai Harta Peninggalan membuat satu daftar tetap dari utang-utang / piutang-piutang yang diakui/ diterima dan daftar ini harus disahkan oleh hakim pengawas, yang kemudian daftar tersebut ditempelkan baik di Pengadilan maupun di Kantor Balai Harta Peninggalan setempat agar sewaktuwaktu dapat dilihat oleh para kreditor / debitor.

8. Melanjutkan usaha debitor atas persetujuan Panitia Kreditor jika ada, dan apabila tidak ada atas persetujuan Hakim Pengawas (Pasal 104);

9. Menyampaikan laporan kepada Hakim Pengawas setiap tiga bulan mengenai keadaan harta pailit dan pelaksanaan tugasnya sebagaimana Pasal 74;

\section{Tugas Balai Harta Peninggalan dalam Pemberesan Harta Pailit :}

Pemberesan adalah penguangan atas semua aset/aktiva debitor dan pada akhirnya setelah itu dibagi kepada kreditor sesuai dengan tingkatan kreditornya ${ }^{8}$.

Dalam tahap pemberesan harta pailit kurator melakukan langkah seperti berikut :

1. Menjual harta/boedel pailit secara lelang ataupun secara di bawah tangan harta kekayaan debitor pailit dengan cara mengajukan permohonan kepada Pengadilan, hakim pengawas hal ini sesuai dengan Pasal 185 Undang-Undang Nomor 37 Tahun 2004 tentang Kepailitan.

2. Penjualan dapat dilakukan dengan cara lelang/secara dibawah tangan dengan lebih dahulu harus mendapat ijin hakim pengawas, ijin ini harus merupakan sebuah penetapan dengan sekaligus menyumpah para juru taksir yang jumlahnya 4 orang untuk barang tetap, sedangkan untuk penaksiran barang bergerak tidak perlu disumpah oleh hakim, karena setiap pegawai Balai Harta Peninggalan yang sudah memenuhi syarat dapat diajukan untuk menjadi juru taksir tetap kepada Pemerintah Daerah (oleh sekwilda setempat).

3. Membuat daftar pembagian untuk disahkan oleh Hakim Pengawas dan mengumumkan daftar pembagian tersebut dalam surat kabar (Pasal 189 jo Pasal 192 ayat (2) ;

4. Pembagian kepada kreditor sesuai daftar pembagian yaitu dengan melakukan pembayaran sesuai daftar pembagian, setelah tenggang waktu sebagaimana dimaksud Pasal 192 atau setelah diajukan perlawanan dan ada keputusan untuk itu (Pasal 201) ;

5. Melakukan tahap penyelesaian dengan cara :

a. Membuat laporan pertanggungjawaban kepada Hakim Pengawas ${ }^{9}$

b. Melakukan pengumuman berakhirnya kepailitan dalam Berita Negara Republik Indonesia dan 
surat kabar sebagaimana dimaksud dalam Pasal 15 ayat (4) jo Pasal 202 ayat (2) UUK-PKPU No. 37 Tahun 2004; Tujuan pengumuman berakhirnya kepailitan adalah agar dapat diketahui oleh khalayak ramai sesuai dengan penetapan Hakim Pengawas.

Balai Harta Peninggalan dalam menjalankan tugas dan kewenangannya tersebut di atas selain berpedoman pada KUH Perdata, Undang-Undang Nomor 37 Tahun 2004 tentang Kepailitan juga didasarkan pada Stbl 1872 No. 166 tentang Instruksi Untuk Balai Harta Peninggalan di Indonesia.

Dalam menjalankan tugasnya untuk mengamankan asset debitor, Balai Harta Peninggalan dengan persetujuan hakim pengawas berwenang untuk menyewa tempat penyimpanan bagi barangbarang yang termasuk dalam harta pailit, selanjutnya menunjuk penjaganya sampai tugas dan kewenangan dalam pengurusan dan pemberesan harta pailit selesai, sebagaimana diatur dalam Pasal 77 Stbl 1872 No. 166 . Menurut Bapak I Nengah Mudani, Ketua Balai Harta Peninggalan Semarang, biaya untuk penyewaan tempat penyimpanan tersebut di atas dibebankan pada harta pailit.

Hasil-hasil penjualan yang dilakukan berdasarkan Pasal 107 Undang- undang Kepailitan, demikian pula uang tunai dan semua penerimaan, disetor ke kas Balai Harta Peninggalan atas rekening debitor, sebagaimana diatur dalam Pasal 78 Stbl 1872 No. 166.

Berkaitan dengan pemberian upah bagi kurator Pasal 76 Undang- Undang Nomor 37 Tahun 2004 tentang kepailitan, sejak diundangkannya Undang-Undang Nomor 37 Tahun 2004 tersebut hingga kini belum diikuti peraturan baru yang mengatur mengenai upah / imbalan jasa Balai Harta Peninggalan, sehingga masih memakai peraturan lama yakni Peraturan Pemerintah Nomor 26 Tahun 1999 tanggal 25 Mei 1999 tentang Tarif atas Jenis Penerimaan Negara Bukan Pajak yang Berlaku pada Departemen Kehakiman.

\section{Eksistensi Balai Harta Peninggalan Semarang sebagai kurator kepailitan dengan adanya kurator swasta.}

Eksistensi Balai Harta Peninggalan sebagai kurator kepailitan dibandingkan dengan kurator swasta dapat dilihat dari data penetapan pengangkatan kurator oleh Hakim di Pengadilan Negeri Semarang berdasarkan hasil penelitian, Balai Harta Peninggalan Semarang melakukan tugas sebagai kurator kepailitan dari data tahun 2009 sampai dengan 2011 adalah sebagai berikut :

\begin{tabular}{|c|c|l|}
\hline NO & Tahun & Jumlah \\
\hline 1 & 2009 & 3 \\
2 & 2010 & 6 \\
3 & 2011 & 1 \\
\hline \multicolumn{2}{|l|}{ Jumlah } & 10 \\
\hline
\end{tabular}

Sumber : Balai Harta Peninggalan Semarang

Sedangkan Hakim mengangkat kurator swasta sebagai kurator dalam menangani kasus-kasus kepailitan di Pengadilan Negeri Semarang dari tahun 2009 sampai dengan tahun 2011 adalah sebagai berikut : 


\begin{tabular}{|c|c|c|}
\hline NO & Tahun & umlah \\
\hline 1 & 2009 & 8 \\
2 & 2010 & 10 \\
3 & 2011 & 13 \\
\hline & Jumlah & 31 \\
\hline
\end{tabular}

Sumber : Panitera Muda Perdata Pengadilan Negeri Semarang.

Berdasarkan daftar yang telah disajikan oleh penulis dalam penelitian ini kurator pemerintah atau Balai Harta Peninggalan Semarang dalam menangani kasus kepailitan lebih sedikit dibandingkan dengan kurator swasta, hal ini dapat dilihat pada tahun 2009 sampai dengan tahun 2011 menangani kasus kepailitan hanya sebanyak 10 kasus. Sedangkan Pengadilan Negeri Semarang mengangkat kurator swasta untuk menangani kasus kepailitan pada tahun 2009 sampai dengan tahun 2011 sebanyak 31 kasus.

Eksisitensi Balai Harta Peninggalan Semarang sebagai Kurator kepailitan menunjukkan penurunan hal ini dapat dilihat pada tahun 2011 menangani kasus kepailitan hanya 1 kasus dibandingkan dengan kurator swasta menangani kasus kepailitan sebanyak 13 kasus, hal ini disebabkan oleh berbagai faktor antara lain :

1. Kurangnya sosialisasi Balai Harta Peninggalan terhadap tugas dan fungsinya sebagai kurator bagi para debitor pailit.

2. Kurangnya koordinasi dengan instansi pemerintah dengan Balai Harta Peninggalan

3. Banyak masyarakat belum tahu bahwa Balai Harta Peninggalan masih ada dan mempunyai tugas dan fungsi dalam masalah kepailitan.

4. Pihak debitor pailit lebih memilih kurator swasta karena dinilai lebih cepat dalam menyelesaikan kasus kepailitan dibandingkan dengan Balai Harta Peninggalan.

5. Sumber daya manusia di Balai Harta Peninggalan yang kurang memadai dalam menanggani kasus kepailitan.

\section{PENUTUP}

\section{Kesimpulan}

Berdasarkan pembahasan yang telah dikemukakan, maka dapat disimpulkan bahwa tugas dan fungsi Balai Harta Peninggalan sebagai kurator kepailitan sesuai dengan Undang-Undang Nomor 37 Tahun 2004 tentang Kepailitan adalah sebagai berikut :

1. Tugas dan fungsi Balai Harta Peninggalan Semarang sebagai kurator dalam menangani harta pailit

Secara garis besar, tugas kurator itu dibagi atas 2 (dua tahap), yaitu tahap pengurusan dan tahap pemberesan. Dalam tahap pengurusan, yaitu jangka waktu sejak debitor dinyatakan pailit sampai debitor dinyatakan insolven (tidak mampu membayar). Yang dilakukan dalam tahap pengurusan ini adalah: mengumumkan putusan pernyataan pailit dalam dua surat kabar dan Berita Negara Republik 
Indonesia sekaligus memanggil debitor / kreditor untuk menghadiri rapat-rapat kreditor dan mendaftarkan tagihan; melakukan inventarisasi / pencatatan harta boedel pailit dan melakukan penyegelan jika dianggap perlu; rapat pencocokan utang (verifikasi); dan apabila dalam rapat verifikasi tiddak ada ditawarkan perdamaian atau perdamaian tidak diterima maka harta / boedel pailit dan setelah itu dilakukan pemberesan. Dalam tahap pemberesan, jangka waktunya adalah setelah debitor pailit insolven dan tidak dilakukan perdamaian. Dalam tahap ini yang dilakukan oleh kurator adalah: menjual harta/boedel pailit; penagihan piutang debitor; membuat daftar pembagian yang disahkan oleh Hakim Pengawas. Setelah dua tugas utama kurator yaitu pengurusan dan pemberesan selesai, maka ada pula tahap penyelesaian yang dilakukan oleh Kurator, yaitu: membuat laporan pertanggungjawaban kepada Hakim Pengawas; mengembalikan surat-surat pribadi debitor; dan mengumumkan berakhirnya kepailitan dalam dua surat kabar dan Berita Negara Republik Indonesia. Setiap tindakan yang dilakukan oleh Kurator, harus mendapat persetujuan dari Hakim pengawas.

2. Eksistensi Balai Harta Peninggalan Semarang sebagai kurator kepailitan dengan adanya kurator swasta.

Eksisitensi Balai Harta Peninggalan Semarang sebagai Kurator kepailitan menunjukkan penurunan hal ini dapat dilihat pada tahun 2011 menangani kasus kepailitan hanya 1 kasus dibandingkan dengan kurator swasta menangani kasus kepailitan sebanyak 13 kasus, hal ini disebabkan oleh berbagai faktor antara lain :

a. Kurangnya sosialisasi Balai Harta Peninggalan terhadap tugas dan fungsinya sebagai kurator bagi para debitor pailit.

b. Kurangnya koordinasi dengan instansi pemerintah dengan Balai Harta Peninggalan.

c. Banyak masyarakat belum tahu bahwa Balai Harta Peninggalan masih ada dan mempunyai tugas dan fungsi dalam masalah kepailitan.

d. Pihak debitor pailit lebih memilih kurator swasta karena dinilai lebih cepat dalam menyelesaikan kasus kepailitan dibandingkan dengan Balai Harta Peninggalan.

e. Sumber daya manusia di Balai Harta Peninggalan yang kurang memadai dalam menanggani kasus kepailitan.

\section{Saran}

1. Kepada Pemerintah untuk bisa mengkaji Undang-Undang Nomor 37 Tahun 2004 tentang Kepailitan dan Penundaan Pembayaran Kewajiban Utang karena dengan melihat kinerja Balai Harta Peninggalan Semarang berkurang setelah adanya kurator swasta

2. Kepada Balai Harta Peninggalan agar bisa mengajukan usulan perubahan terhadap undang-undang nomor 37 tahun 2004. 


\section{DAFTAR PUSTAKA}

Ashshof Burhan, Metode Penelitian Hukum, Jakarta : Penerbit Rineka Cipta, 2004.

Asikin Zainal, Hukum Kepailitan dan Penundaaan Pembayaran di Indonesia, Jakarta; Rajawali Pres 2001.

Djohansyah J., Pengadilan Niaga, dalam Rudy Lontoh (editor), Penyelesaian Utang Melalui Pailit dan Penundaan Kewajiban Pembayaran Utang, Bandung; Alumni 2001.

Hartono Redjeki Sri, Hukum Perdata sebagai Dasar Hukum Kepailitan Modern, Jurnal Hukum Bisnis, Volume 7, Jakarta : Yayasan Pengembangan Hukum Bisnis, 1999.

Jono, Hukum Kepailitan, Jakarta, Sinar Grafika, 2008.

Kashadi dan Patrik Purwahid, Hukum Jaminan Edisi Revisi Dengan UUHT, Semarang : Fakultas Hukum Diponegoro, 1998.

Levinthal E Louis., The Early Hitory of Bankruptcy Law dalam Jordan et al Bankcruptsy, New York; Foundation Press, 1999.

Mudani Nengah I, Pembudayaan dan Pemasyarakatan Materi Balai Harta Peninggalan, Balai Harta Peninggalan Semarang, tahun 2012.

Radin, The Nature of Bankruptcy, dalam Jordan et al Bankcruptsy, New York ; Foundation Press, 1999.

Sastrawidjaja Man., Hukum Kepailitan dan Penundaan Kewajiban Pembayaran Utang, Bandung : Alumni, 2006

Sjahdeini Remy Sutan, Hukum Kepailitan : Memahami Undang-Undang nomor 37 Tahun 20004 Tentang Kepailitan, Jakarta : PT. Pustaka Utama Grafiti, 2009.

Soekarso Hendri dan Situmorang M Victor, Pengantar Hukum Kepailitan di Indonesia, Jakarta: Rineka Cipta, 1994.

Soemitro Hanitijo, Ronny., Metode Penelitian Hukum dan Jurimetri, Jakarta : PT. Ghalia Indonesia, 1990.

Suharsimi Arikunto, Prosedur Penelitian Suatu Pendekatan Praktek, Jakarta: Penerbit Rineka Cipta, 2006.

Sutedi Adrian, Hukum Kepailitan, Bogor: Ghalia, 2009.

Tumbuan B. G Frederick, Naskah Akademik Peraturan Perundang-undangan tentang Kepailitan Pengganti Faillisement Verordening Stb, 1905-217 jo Stb, 1906-348, BPHN Departemen Kehakiman Republik Indonesia, 1994 


\section{Peraturan perundang-undangan:}

Departemen Kehakiman RI. Staatsblad 1872 No. 166 tetang Instruksi untuk Balai Harta Peninggalan di Indonesia. Jakarta, 2001.

Departemen Hukum dan Hak Asasi Manusia RI. Undang-Undang Nomor 37 Tahun 2004 tentang Kepailitan dan Penundaan Pembayaran Utang

Kitab Undang-Undang Hukum Perdata

\section{Website:}

Hukum Kepailitan : Pengertian Kepailitan menurut para sarjana, (http://mknunsri.blogspot.com/2009/10/kepailitan. html,. 